\title{
The effect of condensed tannins in Lotus corniculatus upon reproductive efficiency and wool production in sheep during late summer and autumn
}

\author{
T.N. BARRY ${ }^{1}$, W.C. McNABB ${ }^{2}$, P.D. KEMP 3 , G.C. WAGHORN ${ }^{2}$, B.R. MIN ${ }^{1,2}$ and A. LUQUE ${ }^{1,2}$ \\ ${ }^{1}$ Institute of Food, Nutrition and Human Health, Massey University, Palmerston North \\ ${ }^{2}$ Nutrition Group, AgResearch, Grasslands Research Centre, Palmerston North \\ ${ }^{3}$ Institute of Natural Resources, Massey University, Palmerston North
}

\begin{abstract}
Mixed age Romeny ewes grazed Lotus corniculatus (23 g condensed tannins (CT) $/ \mathrm{kg} \mathrm{DM}$ ) and perennial ryegrass-white clover pasture $(1 \mathrm{~g} \mathrm{CT} /$ $\mathrm{kg} \mathrm{DM}$ ) during the late summer/autumn of 1997 (Experiment 1) and 1998 (Experiment 2). Ewes were in thin condition and weighed $54 \mathrm{~kg}$ in Experiment 1 and were fat and weighed $60 \mathrm{~kg}$ in Experiment 2. Oestrus was synchronised for two cycles in Experiment 1 and four cycles in Experiment 2. Ewes were grazed at maintenance for the first 10 days of each oestrus cycle and then $a d$ libitum for the last 6 days, including ovulation. Half the ewes grazing L. corniculatus were drenched twice daily with polyethylene glycol (PEG), to inactivate the condensed tannins.

Relative to ewes grazing pasture, grazing ewes on $L$. corniculatus increased both ovulation rate (OR) and wool production, with the response in OR being greater in Experiment 1 (34\%) than in Experiment $2(13 \%)$. Maximum increase in OR occurred after grazing lotus for two cycles (5 weeks). Increases in fecundity were caused by a reduction in the proportion of ewes exhibiting single ovulation and increases in the proportions having doubled and triple or quadruple ovulations. As judged by responses to PEG supplementation, part of the L. corniculatus response in OR could be explained by action of CT in Experiment 1 but not in Experiment 2. As voluntary feed intake was similar between the treatments, feeding $L$. corniculatus improved the efficiency with which ingested nutrients were used for reproduction and wool growth. It was concluded that grazing $L$. corniculatus during autumn has most potential for increasing OR in lighter ewes.
\end{abstract}

Keywords: condensed tannin, forage, Lotus corniculatus, nutritive value, ovulation rate, wool growth

Abbreviations: CL, corpora lutea; CT, condensed tannins; DM, dry matter; LWG, liveweight gain; N, nitrogen; OF extrusa, oesophagus fistulated sheep; OM, organic matter; OMD, in vitro organic matter digestibility; OR, ovulation rate; PEG, polyethelene glycol; VFI, voluntary feed intake.

\section{Introduction}

Wool growth has been long known to respond to increasing protein absorption (Reis 1979), whilst the proportion of multiple ovulations (OR) in ewes has also been shown to increase with increasing protein absorption (Cruickshank et al. 1988; Smith 1991). Action of condensed tannins (CT) in Lotus corniculatus is known to increase protein absorption from the small intestine (Waghorn et al. 1987) and to increase both wool growth and milk protein secretion in grazing sheep (Wang et al. 1996a,b; Min et al. 1998). L. corniculatus is a forage legume adapted to acid, medium fertility soils in areas with dry summers (Scott \& Charlton 1983). The objective of the work reported here was to determine the effect of grazing L. corniculatus, and specifically its CT content, upon the OR and wool production of ewes during autumn. A control group of ewes grazed perennial ryegrass-white clover pasture, which contained only traces of CT.

\section{Materials and methods}

Mixed age Romney ewes were used in two grazing experiments during the late summer/autumn of 1997 (Experiment 1) and 1998 (Experiment 2). Mean initial liveweights were respectively $54.2 \mathrm{~kg}$ (SE 0.88 ) and $59.8 \mathrm{~kg}$ (SE 0.4). The ewes were in lean condition during Experiment 1 but were in fat condition in Experiment 2. In both experiments oestrus was synchronised using controlled release intravaginal devices (CIDR; Carter Holt Harvey), containing $0.3 \mathrm{~g}$ progesterone. Two oestrus cycles were studied in Experiment 1 and four oestrus cycles were studied in Experiment 2. Ewes were mated with vasectomised rams in earlier cycles and with entire rams for the final cycle in each experiment; all rams were fitted with harnesses and crayons to identify ewes exhibiting oestrus. OR was determined at the end of each cycle by counting corpora lutea (CL) using laparoscopy (Kelly \& Allison 1976), approx. 7 days after mating. 
The ewes $(n=100 /$ treatment group $)$ grazed perennial ryegrass-white clover pasture or pure $L$. corniculatus at maintenance for the first 10 days of each 16-day oestrus cycle (allowance $1.3 \mathrm{~kg} \mathrm{DM} /$ ewe/ d). The allowance was increased to ad libitum $(2.2 \mathrm{~kg}$ $\mathrm{DM} / \mathrm{ewe} / \mathrm{d}$ ) during the last 6 days of each oestrus cycle, including ovulation. These allowances were maintained using small paddocks divided in half with electric fences, so that all ewes received breaks lasting 3 or 4 days.

After the last oestrus cycle, the ewes continued grazing their respective forages for another 4 weeks, when voluntary feed intake (VFI) was determined using intra-ruminal slow release chromium capsules (Nufarm, Auckland), with diet selected determined from samples of extrusa collected from sheep fistulated in the oesophagus (OF extrusa). The sheep were shorn in early February, just before each experiment commenced, and again when the experiments concluded (late April/ early May).

In both experiments, half the ewes grazing $L$. corniculatus $(\mathrm{n}=50 /$ treatment group) were drenched twice daily with polyethylene glycol (PEG; MW 3350) to bind and inactivate the CT. The amount given was $70 \mathrm{~g} /$ day for the first 10 days of each oestrus cycle when the ewes were on maintenance feeding, increasing to $110 \mathrm{~g}$ /day during the final 6 days of each oestrus cycle when the ewes were fed ad libitum. These quantities were sufficient to bind all the CT consumed in L. corniculatus at the levels of DM intake encountered in this study (Barry \& Forss 1983). This was also done for ewes grazing pasture in Experiment 1, to check that PEG drenching did not affect wool growth and $\mathrm{OR}$ in ewes grazing a forage containing only traces of CT.

Pasture mass was determined by cutting eight samples to ground level before and after grazing each paddock and drying at $95^{\circ} \mathrm{C}$ for $17 \mathrm{hr}$. Samples of feed on offer were similarly taken by cutting eight samples per paddock to ground level before grazing each area and pooling the samples. All sheep were weighed every 2 weeks and grazing areas adjusted such that the ewes were kept at maintenance for the first 10 days of each oestrus cycle and gained weight during ad libitum feeding.

Laboratory methods used and other experimental details are given by Min et al. (1999). Ovulation data are presented first as mean OR, and then after statistical analysis to determine treatment effects upon ewes ovulating/ewes mated and fecundity (CL/ewe ovulating). Fecundity is presented as the percentage of ewes having single or multiple ovulations. Ovulation data were transformed using Logistic Regression (SAS 1995) and treatment effects established using the Chisquared procedure (Smith 1985). Treatment effects upon VFI, liveweight gain (LWG) and clean fleece weight were determined using General Linear Models (SAS 1995).

\section{Results}

Forage mass before grazing was generally higher for $L$. corniculatus than for pasture, but forage mass after grazing was similar for the two forages and was higher after ad libitum grazing than after maintenance grazing (Table 1).

Herbage in vitro organic matter digestibility (OMD) and total nitrogen $(\mathrm{N})$ concentration were higher in $(\mathrm{P}<0.05)$ samples of diet selected (OF extrusa) than herbage on offer (Table 2). OMD tended to be higher for $L$. corniculatus than for pasture, whilst the reverse was true for total $\mathrm{N}$ concentration in Experiment 1 but not Experiment 2. Total CT concentration was approximately $23 \mathrm{~g} / \mathrm{kg}$ DM for $L$. corniculatus, whilst the pasture contained only traces of CT (approx. $1 \mathrm{~g} / \mathrm{kg}$ DM).

Table 1 Pre-grazing and post-grazing forage mass (t DM/ha) of two pasture types and two feeding levels in two sheep grazed experiments.

\begin{tabular}{|c|c|c|c|c|c|}
\hline \multirow[b]{2}{*}{ Feeding level } & \multicolumn{2}{|c|}{---------- Pasture ---------- } & \multicolumn{2}{|c|}{------------ Lotus ------------ } & \multirow[t]{2}{*}{ SE } \\
\hline & Pre-grazing & Post-grazing & Pre-grazing & Post-grazing & \\
\hline \multicolumn{6}{|l|}{$\begin{array}{l}\text { Experiment } 1 \\
\text { (1997) }\end{array}$} \\
\hline Maintenance & 2.49 & 1.12 & 2.06 & 0.61 & 0.144 \\
\hline Ad libitum & 2.80 & 1.44 & 3.23 & 1.40 & 0.208 \\
\hline \multicolumn{6}{|l|}{$\begin{array}{l}\text { Experiment } 2 \\
(1998)\end{array}$} \\
\hline Maintenance & 2.60 & 1.00 & 3.63 & 0.99 & 0.095 \\
\hline Ad libitum & 2.77 & 1.21 & 4.00 & 1.27 & 0.265 \\
\hline
\end{tabular}

Table 2 Chemical composition of feed on offer and diet selected by sheep grazing two pasture types and under two feeding levels, in two experiments.

\begin{tabular}{|c|c|c|c|c|c|}
\hline & --Feed o & ר offer-- & --Diet se & ected-- & SE \\
\hline & Pasture & Lotus & Pasture & Lotus & \\
\hline Experiment 1 (1997) & & & & & \\
\hline $\begin{array}{l}\text { In vitro OMD } \\
(\% \mathrm{OM})\end{array}$ & 64.9 & 78.7 & 81.8 & 84.4 & 3.60 \\
\hline Total N (g/kg OM) & 41.5 & 29.0 & 49.6 & 41.1 & 0.43 \\
\hline Total CT (g/kg DM) & 1.1 & 23.1 & 4.1 & 16.5 & 0.62 \\
\hline Experiment 2 (1998) & & & & & \\
\hline $\begin{array}{l}\text { In vitro OMD } \\
(\% \text { OM) }\end{array}$ & 55.2 & 63.9 & 76.3 & 80.3 & 1.24 \\
\hline Total N (g/kg OM) & 17.4 & 22.6 & 40.8 & 36.5 & 3.32 \\
\hline Total CT (g/kg DM) & $\mathrm{ND}^{1}$ & ND & 1.3 & 23.7 & 0.61 \\
\hline
\end{tabular}


Mean OR in both experiments was consistently higher for unsupplemented sheep grazing $L$. corniculatus than for unsupplemented sheep grazing pasture (Table 3). Maximum response was obtained after two cycles of grazing on $L$. corniculatus.

Ewes ovulating/ewes mated in Experiment 1 was $98 \%$ in cycle 1 and $100 \%$ in cycle 2, whilst in Experiment 2 it was respectively $99.6,96.7,97.7$ and $92.0 \%$ for cycles 1, 2, 3, and 4. Ewes ovulating/ewes mated was not affected by the nutritional treatments applied in either experiment.

In Experiment 1, fecundity of ewes grazing $L$. corniculatus was greater than that of ewes grazing pasture during cycle $2(\mathrm{P}<0.01)$ (Table 4$)$, with this trend becoming apparent during cycle $1(\mathrm{P}<0.11)$. During cycle
2, fecundity of unsupplemented (i.e., CT - acting) ewes grazing L. corniculatus was greater than that of PEGsupplemented ewes (CT not acting; $\mathrm{P}=0.06$ ). Increases in fecundity due to both lotus feeding and action of $\mathrm{CT}$ were due to fewer single ovulations and more double and triple or quadruple ovulations. In Experiment 2, fecundity of ewes grazing $L$. corniculatus was greater than that for ewes grazing pasture during cycle $1(\mathrm{P}<0.07)$, cycle 2 $(\mathrm{P}<0.05)$ and cycle $3(\mathrm{P}<0.05)$, with there being no effect during cycle 4 (Table 4). Unlike Experiment 1, PEG supplementation of ewes grazing $L$. corniculatus had no effect upon fecundity in Experiment 2.

VFI in either experiment was not affected by the nutritional treatments applied (Table 5). Over the complete experimental period, ewes showed a small

Table 3 Ovulation rates (OR) in ewes grazing two pasture types, with or without PEG supplementation to inactivate condensed tannins (CT).

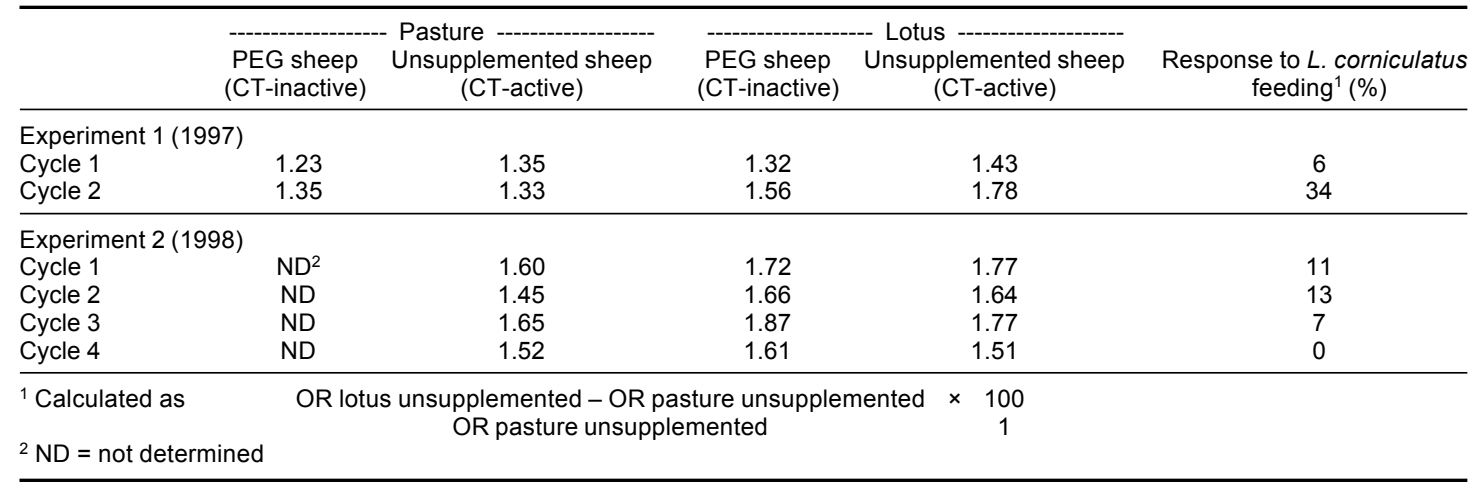

Table 4 Effect of grazing ewes on $L$. corniculatus or perennial ryegrass-white clover pasture and of PEG supplementation to inactivate condensed tannins (CT) upon fecundity at ovulation (corpora lutea $x$ 100/ewe ovulating).

\begin{tabular}{|c|c|c|c|c|c|c|}
\hline & \multirow[b]{2}{*}{$\begin{array}{l}\text { Number of } \\
\text { ovulations }\end{array}$} & \multicolumn{2}{|c|}{---------------- Pasture ---------------- } & \multicolumn{2}{|c|}{---------------- Lotus ---------------- } & \multirow[t]{2}{*}{ SE } \\
\hline & & $\begin{array}{c}\text { PEG } \\
\text { sheep } \\
\text { (CT-inactive) }\end{array}$ & $\begin{array}{l}\text { Unsupplemented } \\
\text { sheep } \\
\text { (CT-active) }\end{array}$ & $\begin{array}{c}\text { PEG } \\
\text { sheep } \\
\text { (CT-inactive) }\end{array}$ & $\begin{array}{c}\text { Unsupplemented } \\
\text { sheep } \\
\text { (CT-active) }\end{array}$ & \\
\hline \multicolumn{7}{|c|}{ Experiment 1 (1997) } \\
\hline Number of ewes & & 50 & 50 & 50 & 50 & \\
\hline \multirow[t]{3}{*}{ Cycle 1} & Single & 74.0 & 69.4 & 62.5 & 59.2 & 0.45 \\
\hline & Double & 26.0 & 26.5 & 35.4 & 38.2 & 0.45 \\
\hline & Triple and quadruple & 0.0 & 4.1 & 2.1 & 2.0 & 0.45 \\
\hline \multirow[t]{3}{*}{ Cycle 2} & Single & 66.7 & 69.4 & 40.8 & 30.6 & 0.60 \\
\hline & Double & 31.4 & 28.6 & 55.1 & 61.2 & 0.60 \\
\hline & Triple and quadruple & 2.0 & 2.0 & 4.1 & 8.2 & 0.60 \\
\hline \multicolumn{7}{|c|}{ Experiment 2 (1998) } \\
\hline Number of ewes & & & 79 & 66 & 66 & \\
\hline \multirow[t]{2}{*}{ Cycle 1} & Single & $\mathrm{ND}^{1}$ & 46.2 & 36.3 & 31.8 & 0.073 \\
\hline & Multiple & ND & 53.9 & 63.4 & 68.2 & 0.073 \\
\hline \multirow[t]{2}{*}{ Cycle 2} & Single & ND & 52.6 & 38.5 & 36.5 & 0.074 \\
\hline & Multiple & ND & 47.4 & 61.5 & 63.5 & 0.074 \\
\hline \multirow[t]{2}{*}{ Cycle 3} & Single & ND & 39.0 & 18.8 & 29.2 & 0.073 \\
\hline & Multiple & ND & 61.0 & 81.3 & 70.8 & 0.073 \\
\hline \multirow[t]{2}{*}{ Cycle 4} & Single & ND & 44.4 & 31.2 & 39.3 & 0.076 \\
\hline & Multiple & ND & 55.6 & 68.9 & 60.7 & 0.076 \\
\hline
\end{tabular}

${ }^{1} \mathrm{ND}=$ Not determined 
Table 5 Effect of grazing ewes on L. corniculatus or perennial ryegrass-white clover pasture and of PEG supplementation to inactivate condensed tannins (CT) upon voluntary feed intake (VFI), liveweight gain (LWG) and clean fleece weight.

\begin{tabular}{|c|c|c|c|c|c|}
\hline & \multicolumn{2}{|c|}{---------------- Pasture ---------------- } & \multicolumn{2}{|c|}{ 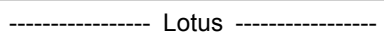 } & \multirow[t]{2}{*}{ SE } \\
\hline & $\begin{array}{c}\text { PEG } \\
\text { sheep } \\
\text { (CT-inactive) }\end{array}$ & $\begin{array}{c}\text { Unsupplemented } \\
\text { sheep } \\
\text { (CT-active) }\end{array}$ & $\begin{array}{c}\text { PEG } \\
\text { sheep } \\
\text { (CT-inactive) }\end{array}$ & $\begin{array}{c}\text { Unsupplemented } \\
\text { sheep } \\
\text { (CT-active) }\end{array}$ & \\
\hline \multicolumn{6}{|l|}{ Experiment 1 (1997) } \\
\hline VFI (kg OM/ewe/d) & 1.98 & 1.83 & 1.85 & 1.70 & 0.087 \\
\hline $\operatorname{LWG}(\mathrm{g} / \mathrm{d})$ & 5 & 19 & 34 & 40 & 6.9 \\
\hline Clean fleece $(\mathrm{kg})$ & 1.14 & 1.09 & 1.31 & 1.35 & 0.027 \\
\hline \multicolumn{6}{|l|}{ Experiment 2 (1998) } \\
\hline VFI (kg OM/ewe/d) & $\mathrm{ND}^{1}$ & 1.78 & 1.86 & 1.96 & 0.09 \\
\hline LWG $(g / d)$ & ND & -12 & -25 & -20 & 6.7 \\
\hline Clean fleece $(\mathrm{kg})$ & ND & 1.54 & 1.69 & 1.73 & 0.029 \\
\hline
\end{tabular}

${ }^{1} \mathrm{ND}=$ not determined

LWG in Experiment 1 which was greater for ewes grazing $L$. corniculatus than pasture $(\mathrm{P}<0.01)$, whilst a small liveweight loss occurred in Experiment 2 that did not differ between the nutritional treatments. Clean fleece weight was greater for ewes grazing L. corniculatus than pasture in both experiments $(\mathrm{P}<0.001)$, with there being no effect of PEG supplementation.

\section{Discussion}

These experiments have shown that relative to ewes grazed on perennial ryegrass-white clover pasture, grazing on L. corniculatus can be used to consistently increase OR. The magnitude of the response was related to the duration of $L$. corniculatus feeding, with the maximum response occurring after feeding for two cycles (5 weeks). As judged by responses to PEG supplementation, part of the OR response in Experiment 1 could be explained by the action of CT in $L$. corniculatus, whereas none of the OR response to $L$. corniculatus in Experiment 2 could be explained by the action of CT. Possible reasons for the difference between experiments is that the lean lighter ewes used in Experiment 1 were more responsive to the additional protein absorption caused by action of $\mathrm{CT}$ than were the fat heavier ewes used in Experiment 2, or that the ewes gained weight in Experiment 1 but lost weight in Experiment 2. It has been deduced that the increase in OR due to action of CT in Experiment 1 was due to increased plasma concentration of essential amino acids and especially the branched chain amino acids (BCAA) (Min et al. 1999). Infusion of BCAA into the blood for 5 days leading up to and including ovulation has been shown to increase OR in sheep (Downing \& Scaramuzzi 1995).

Whilst the feeding of L. corniculatus produced increases in wool production (11-20\%), none of the increase could be explained by the action of CT. As the diet selected by sheep grazing L. corniculatus was higher in OMD but lower in total $\mathrm{N}$ content than that of sheep grazing pasture, it is probable that the increased wool production from grazing $L$. corniculatus was due to an increased supply of microbial protein.

As VFI was similar for sheep grazing the two forages, it seems that the increases in reproductive efficiency and wool production from feeding $L$. corniculatus were due to improved utilisation of ingested nutrients. From the present studies it seems that action of CT in $L$. corniculatus has the greatest effect in increasing reproductive efficiency when lean light ewes are used, and this has been confirmed in a 1999 study which also recommended grazing $L$. corniculatus for three cycles (7 weeks) (Min, Barry, McNabb, Kemp and McDonald unpublished data). From an agronomic point of view, $L$. corniculatus grows best in dry East Coast areas of New Zealand, where ewe liveweights are also likely to be lowest. Thus it may find application in these areas, especially if only 5-7 weeks of grazing during autumn are required in order to increase reproductive efficiency.

\section{ACKNOWLEDGEMENTS}

This study was financed through a grant from the Wool Pro Division of the New Zealand Wool Board. Mr G.S. Purchas, Mr J.S. Peters and staff of the Nutrition Laboratory, Institute of Food, Nutrition and Human Health, Massey University are thanked for skilled technical assistance. Dr P.C.H. Morel and Professor D.J. Garrick are thanked for advice with statistical analysis and Mr T.G. Harvey is thanked for advice on grazing management.

\section{REFERENCES}

Barry, T.N.; Forss, D.A. 1983. The condensed tannin content of vegetative Lotus pedunculatus, its 
regulation by fertiliser application and effect upon protein solubility. Journal of the science of food and agriculture 34: 1047-1056.

Cruickshank, G.J.; Smith, J.F.; Fraser, D.G. 1988. The influence of abomasal Infusion of protein or energy on ovulation rate in ewes. Proceedings of the New Zealand Society of Animal Production 48: 77-79.

Downing, J.A.; Joss, J.; Scaramuzzi, R.J. 1995. A mixture of the branched chain amino acids leucine, isoleucine and valine increases ovulation rate in ewes when infused during the late leteal phase of the oestrus cycle: an effect that may be mediated by insulin. Journal of endocrinology 145: 315-323.

Kelly, R.W.; Allison, A.J. 1976. Measurements of ovulation rates by laparoscopy and effects on reproductive performance. Proceedings of the New Zealand Society of Animal Production 36: 240246.

Min, B.R.; Barry, T.N.; McNabb, W.C.; Kemp, P.D. 1998. The effect of condensed tannins on the production of wool and on its processing characteristics in sheep grazing L. corniculatus. Australian journal of agricultural research 49: 597-605.

Min, B.R.; McNabb, W.C.; Barry, T.N.; Kemp, P.D.; Waghorn, G.C.; McDonald, M.F. (In Press). The effect of condensed tannins in L. corniculatus upon reproductive efficiency and wool production in sheep during late summer and autumn. Journal of agricultural science, Cambridge.

Reis, P.J. 1979. Effects of amino acids on the growth and properties of wool. pp. 223-242. In: Physiological and environmental limitations to wool growth. Eds. Black, J.L.; Risi, J. Armidale, New
South Wales, University of New England Publishing Unit.

Scott, D.; Charlton, J.F.L. 1983. Birdsfoot trefoil ( $L$. corniculatus) as a potential dryland/herbage legume in New Zealand. Proceedings of the New Zealand Grassland Association 44: 98-105.

Smith, J.F. 1985. Protein, energy and ovulation rate. pp. 349-359. In: Genetics of reproduction in sheep. Eds. Land, R.B.; Robinson, D.W. London, Butterworth Scientific.

Smith, J.F. 1991. A review of recent developments on the effect of nutrition on ovulation rate (the flushing effect) with particular reference to research at Ruakura. Proceedings of the New Zealand Society of Animal Production 51: 15-23.

Statistical Analysis System 1995. Version 6. North Carolina, USA, SAS Institute.

Waghorn, G.C.; Ulyatt, M.J.; John, A.; Fisher, M.T. 1987. The effect of condensed tannins on the site of digestion of amino acids and other nutrients in sheep fed on L. corniculatus L. British journal of nutrition 57: 115-126.

Wang, Y.; Douglas, G.B.; Waghorn, G.C.; Barry, T.N.; Foote, A.G. 1996a. Effects of condensed tannin in L. corniculatus upon lactation performance in ewes. Journal of agricultural science, Cambridge 126: 353-362.

Wang, Y.; Douglas, G.B.; Waghorn, G.C.; Barry, T.N.; Foote, A.G.; Purchas, R.W. 1996b. Effect of condensed tannins upon the performance of lambs grazing L. corniculatus and lucerne (Medicago sativa). Journal of agricultural science, Cambridge 126: 87-98. 
